\title{
Traducerea: între ce se poate traduce și ce trebuie tradus
}

\author{
Magda Jeanrenaud* \\ Facultatea de Litere, Universitatea „Alexandru Ioan Cuza”, Bd. Carol I 11, 700506 Iaşi, România
}

\author{
Despre articol \\ Istoric: \\ Cuvinte-cheie: \\ traducere \\ intenționalitate \\ skopos \\ coerență \\ (in)traductibilitate \\ sintaxă \\ poetică
}

Primit 9 noiembrie 2015

Acceptat 29 noiembrie 2015

Publicat 12 februarie 2016

\begin{abstract}
Rezumat
Pornind de la o tulburătoare interpretare a lui Jacques Derrida, studiul de față își propune să investigheze și încearcă să explice blocajul ce intervine în versiunile englezești, franceze și românești (semnate de Antoine Berman, Alexis Nouss, Steven Rendall, Catrinel Pleșu etc.) ale celebrului text al lui Walter Benjamin, Die Aufgabe des Übersetzers, atunci cînd traducătorii transpun în cele trei limbi țintă cele două citate cuprinse în acesta: un citat din Mallarmé, lăsat netradus de Benjamin însuşi, și un altul, din Pannwitz. Într-un fel sau altul, ambele citate au o formă discursivă ce lasă să se întrevadă o sintaxă ce se abate deliberat de la normă, ca și cum ar fi deja niște „traduceri”. Analiza mai pune în evidență și comportamentul (cumva o dominantă a psihologiei traducătorilor?) celor ce au transpus textul benjaminian, comportament marcat de obsesia lizibilității văzută ca o trăsătură congenitală a oricărei traduceri, chiar și atunci cînd textul original nu tinde spre aceasta. De unde și dilema, dureroasă, legată de spinoasa chestiune a intenționalității textului (nu doar de tradus)...
\end{abstract}

\section{Intenționalitatea textului: o chestiune la fel de spinoasă...}

Așa cum s-a construit ea începînd cu anii '70 ai secolului trecut, traductologia, ca și practica traductivă însăşi, au avut mult de cîștigat în ce privește gestionarea binomului traductibil-intraductibil (pe care nici comparatismul, nici modelele de inspirație lingvistică nu știuseră cum să-l administreze), mai ales prin flexibilizarea modalităților de percepție a legăturilor dintre textul tradus și textul original, altfel spus a reprezentărilor privind raportul fidelitate /infidelitate.

Un prim pas s-a făcut în anii '70, cînd teoria literară de sorginte structuralistă a proclamat, prin vocea lui Roland Barthes, „moartea autorului”: s-a pus astfel sub semnul întrebării însăși pertinența mai vechii noțiuni de „intenționalitate”, altfel spus caracterul operațional din punct de vedere teoretic al raportului text-autor, dar și „,responsabilitatea” celui din urmă vizavi de sensul și semnificația textului ${ }^{1}$. Ceea ce s-a numit, cu o formulă lansată de New Criticism-ul american, intentional fallacy, utopia intenționalității, nu putea decît să aducă prejudicii teoriei literare: în fond, ea reflecta conflictul dintre explicația literară (examenul intențiilor autorului, a ceea ce a vrut el să spună în propriul text) și interpretarea literară (descrierea semnificațiilor operei independent de intențiile autorului). Excluderea autorului ar fi trebuit astfel să contribuie la autonomizarea cercetării literare în raport cu istoria și psihologia, așezînd-o, datorită postulatelor literarității și autotelismului inspirate de formalismul rus și de Roman Jakobson pe baze „interne”, „imanente”, literaritatea rezultînd, ca o componentă autonomă, din înseși particularitățile organizării materialului ce alcătuiește opera. Lipsit de „origine”, textul exploda sub presiunea unei polisemii ridicate la rangul de principiu constitutiv, dezvăluind astfel în cele din urmă propria natură intertextuală. Doar o nouă instanță, care era pe cale de a se consolida în calitate de concept teoretic, ar fi putut să-i confere o coerență, reconstituindu-i unitatea risipită într-un „mozaic de citate”: cititorul.

Hermeneutica și estetica receptării aveau să confirme în mod strălucit faptul că semnificaţia textului depășește intenționalitatea autorului, deoarece acumulează, prin însăși existența sa în diacronie, noi straturi de sens, care nu puteau fi anticipate nici de autor și, cu atît mai puțin, de cei dintîi cititori ai săi; sensul

*Adresă de corespondență: mjeanrenaud@hotmail.com.

${ }^{1}$ Am dezvoltat această temă și în Jeanrenaud (2006, p. 237-251), și apoi în Jeanrenaud (2012, p. 33-49). 
unui text se coagulează astfel în funcție de modul în care este ,interogat” de un subiect condiționat istoric, el însuşi preocupat să descifreze inclusiv „întrebarea” la care textul a încercat să răspundă în propriu-i context. Textul nu mai cuprinde doar un sens_-imuabil și interpretabil ca atare de la o receptare la alta-, ci și o semnificație, în virtutea căreia se articulează în jurul unei situații, contextualizîndu-se în funcție de coordonatele fiecărei noi receptări. Dacă sensul înlesnește stabilitatea receptării, semnificația explică variațiile receptării unui text: sensul este singular, în timp ce semnificația este deschisă, plurală, inepuizabilă și, la limită, infinită. Dar dacă adecvarea, profunzimea unei interpretări depindeau de capacitatea ei de a scoate la lumină coerența și complexitatea unui text, atunci însuși criteriul coerenței, care păruse în stare să scurtcircuiteze instanța autorului, nu putea fi conceput fără a se recurge la ceea ce Antoine Compagnon numise „prezumția de intenționalitate” (Compagnon, 1998, p. 13-101) sau, în orice caz, probabilitatea unei intenții, premisă fără de care acesta se golea orice pertinență conceptuală.

$\mathrm{Nu}$ din întîmplare s-a înzestrat practica traducerii cu o reflecție teoretică tot mai intensă într-o perioadă ce păruse gata să îmbrățișeze pretențiile hegemonice şi scientiste ale lingvisticii, învestindu-le cu puterile unei metode de cunoaștere exhaustivă, de altfel curînd detronată de cei ce au atras atenția asupra pericolelor „mirajului” (Pavel, 1988) lingvistic. După o perioadă în care așteptările lingvisticii, aflată în căutarea unui banc de experiment menit a-i ilustra postulatele, au părut a se împlini, limitele unui model exclusiv lingvistic al traducerii au devenit evidente. Însăşi perspectiva saussuriană, care vedea în limbi sisteme etanșe, în interiorul cărora semnul se înzestra cu o semnificație (valoare) ce se coagula exclusiv în virtutea raporturilor sale cu celelalte semne ale limbii, confirma din punct de vedere teoretic aporia intraductibilității, adîncind concomitent prăpastia dintre practica traducerii și imposibilitatea ei teoretică: diferențele lingvistice dintre limbi nu puteau decît să întărească ipoteza intraductibilităţii, legitimată de un Roman Jakobson atunci cînd lansa formula conform căreia limbile se deosebesc nu prin ce pot să exprime, ci prin ce trebuie să exprime².

Dincolo de perspectiva strict lingvistică, care ar fi ezitat să accepte posibilitatea traducerii unuia și aceluiași termen printr-o serie de echivalențe a căror selecție să se facă în funcție de conformitatea la contextul din care face acesta parte, reflecția asupra traducerii s-a deplasat astfel din ce în ce mai mult spre o perspectivă „comunicațională”, ce asimila semnificațiile verbale cu niște variabile supuse influenței factorilor exteriori. Dat fiind că textul nu se constituie doar pe baza acțiunii mecanismelor lingvistice, acestora li se adaugă un întreg evantai de elemente extralingvistice, în virtutea cărora competenței lingvistice i se asociază o competență textuală: noțiunea de ipoteză de sens subliniază ideea după care comprehensiunea enunțului decurge nu doar din cunoașterea unei limbi, ci și din cunoașterea unei lumi.

Criteriul coerenței și complexității nu se poate justifica înafara unei intenționalități, în lipsa căreia opera ar apărea ca un fel de consecință a hazardului (Compagnon, 1998, p. 97): or, tocmai această capacitate de a recunoaște intenționalitatea-în-coerență pare să pună probleme în materie de traducere și contribuie adesea, prin ricoșeu, la a alimenta fantasma intraductibilului ${ }^{3}$. Fapt este că, de-a lungul timpului, şi în toate epocile, intraductibilitatea a reverberat cînd asupra literei (forma), cînd a sensului (conțintul) şi, în cel mai rău caz, asupra amîndorura: la urma urmelor, temerarul Vocabulaire européen des philosophies (Cassin, 2004) elaborat de o echipă de cercetători coordonați de Barbara Cassin poartă amprenta acestei ambiguități, de vreme ce anunță, încă de la subtitlu, că este vorba și de un dicționar al termenilor

\footnotetext{
${ }^{2} J a k o b s o n$ (1959, p. 236), reluat în Jakobson (1971, p. 264) şi în Venuti (2000, p. 115): „Languages differ essentially in what they must convey and not in what they may convey”. Iată și versiunea franceză a celebrei maxime: „Les langues differrent essentiellement par ce qu'elles doivent exprimer, et non par ce qu'elles peuvent exprimer” (Jakobson, 1963, p. 84).

${ }^{3}$ Unui Julien Green care susținea că a traduce în franceză the mystic moon dintr-un vers al lui E. A. Poe prin la lune mystique nu face decît să-l transforme într-un „libret de operă fără muzică”, Georges Mounin i-a dat următoarea replică: a spune la lune mystique este pur și simplu o platitudine, dublată, în plus, de un contrasens, pentru că adjectivul englez folosit de Poe respiră bogăţia aluzivă a tuturor nuanțelor, diferite de sensul său francez, pe care le posedă în engleză, unde a păstrat sensul propriu al cuvintului mystic, împrumutat direct din greaca veche, 'secret, tainic'. Departe de a fi intraductibilă, imaginea era pur și simplu... tradusă neîndemînatec. Ea ar fi trebuit, mai spune Mounin, să sugereze o atitudine inițiatică, și atunci la lune sacrée s-ar fi potrivit mai bine sau la lune secrète și poate chiar la lune scellée 'luna pecetluită, formulă ce conține sferele semantice ale lui secrète și sacrée și care creează în același timp și imaginea cea mai puternică, cf. Mounin (1994, p. 52-53).
} 
intraductibili...

\section{2. ...ca euforia traductibilității nelimitate}

Însă nici nu ar trebui să cădem în euforia traductibilității nelimitate, ceea ce mi se pare la fel de riscant ca și înălțarea intraductibilului la rang de deznodămînt inconturnabil al traducerii. Dacă este adevărat că nu orice se poate traduce, ar mai trebui și să recunoaștem intraductibilitatea acolo unde ea decurge din chiar intenționalitatea textului de tradus, și să ne întrebăm, inversînd o splendidă constatare a lui Jacques Derrida $^{4}$, dacă el „se lasă” tradus ca fiind traductibil.

Aș dori așadar să mă opresc mai îndelung asupra foarte cunoscutului eseu al lui Walter Benjamin, intitulat Die Aufgabe des Übersetzers (Benjamin, 1972), și, în special, asupra modului în care traducătorii francezi, englezi și traducătoarea româncă au procedat în cazul a două citate date în acest text. Eseul a fost tradus în limba română, unde există două versiuni, semnate de aceeași traducătoare, Catrinel Pleșu, dar publicate de două edituri diferite, sub titlul Sarcina traducătorului (Benjamin, 2000b, 2002); mă voi referi și la versiunea franceză, intitulată La tâche du traducteur (1971), semnată de Maurice de Gandillac (Benjamin, 1971, 2000a), și la cea mai recentă, semnată de Martine Broda (Benjamin, 1991); voi mai invoca alte două versiuni franceze, dintre care una este traducerea parțială a lui Antoine Berman în cadrul unui seminar de traductologie privind interpretarea și comentariul textului benjaminian, ținut în iarna 1984-19855; în fine, voi evoca două versiuni engleze, intitulate The Task of the Translator (Benjamin, 1968), semnată de Harry Zohn, și The Translator's Task (Benjamin, 1997), semnată de Steven Rendall.

Chiar dacă nu este înregistrat de dicționarul termenilor intraductibili coordonat de Barbara Cassin, cuvîntul german Aufgabe pare a dispune de o sferă semantică mai largă decît echivalențele sale din limbile română, engleză și franceză, de vreme ce Jacques Derrida îi asociază sensul nu doar cu o sarcină, ci și cu o misiune, o îndatorire (în cele două accepțiuni ale cuvîntului românesc sarcină, datorie, dar și misiune), un angajament în virtutea căruia traducătorul contractează o datorie, sarcina lui constînd în a se elibera de aceasta printr-o donație (Derrida, 1998, p. 211). Inspirîndu-se din comentariul lui Derrida, care observa și că verbul german aufgeben trimite nu doar la o donație, ci și la un abandon (Derrida, 1998, p. 212), și profitînd de resursele familiei lexicale ale termenului francez don, o retraducere mai recentă a textului lui Benjamin, făcută de Alexis Nouss și Laurent Lamy, îndrăznește să propună titlul L'abandon du traducteur (Lamy \& Nouss, 1997) și actualizează, de-a lungul întregului text, polisemia lui Aufgabe, jucînd pe cuplul tâche - abandon (sarcină - abandonare, renunțare) și lexicalizînd astfel acel du-te-vino dintre traductibil și intraductibil, dintre sarcină și eșecul ei, camullate în nucleul semantic al lui Aufgabe, însă posibil de descifrat în însăși intenționalitatea textului sursă, în coerența lui, ce funcționează pe ambele traiectorii semantice.

În textul lui Benjamin există, cum spuneam, două citate, iar analiza mea se va concentra asupra transpunerii lor în română, engleză şi franceză (în cazul celui de-al doilea). Spre sfirșitul eseului, Walter Benjamin citează, în franceză, o frază din Mallarmé, pe care o lasă netradusă, după ce invocase la începutul paragrafului, în latină, ingenium (a se vedea Anexa A). Termenul latinesc este tradus de Harry Zohn în engleză (philosophical genius) și de Gandillac și Martine Broda prin génie: această reticență vizavi de decizia de a lăsa termenul latinesc spune mult despre distanța care ne desparte de vremurile cînd latina era limba inconturnabilă a științei și filozofiei... Pe de altă parte, opțiunea celor doi traducători francezi deschide larg porțile în fața a ceea ce poartă numele de traducere etnocentrică, naturalizantă, de vreme ce îl va împinge pe cititor spre un concept franco-francez, acel „montaj ideologic” încă adînc înrădăcinat în mentalităţile

\footnotetext{
${ }^{4}$ Întrebîndu-se cum trebuie tradus un text scris în mai multe limbi, Jacques Derrida observa că „Nu ar trebui să trecem niciodată sub tăcere chestiunea limbii în care se pune chestiunea limbii și este tradus un discurs despre traducere” (Derrida, 1998, p. 204; traducerea îmi aparține) [„One should never pass over in silence the question of the tongue in which the question of the tongue is raised and into which a discourse on translation is translated" (Derrida, 2007, p. 192)].

${ }^{5}$ Seminarul a avut loc la „Collège international de philosophie”, iar textul a fost reconstituit, după dispariția lui Antoine Berman, după notele sale și o sumă de înregistrări, cf. Berman (2008).

${ }^{6}$ Începînd din secolul al XVI-lea și culminînd cu discursul despre universalitatea limbii franceze al lui Rivarol (1782), teza
} 
franceze, îndepărtîndu-l astfel pe nesimțite de sensul pe care are a-l reține, cel al unei proprietăți înnăscute a spiritului filozofic.

Versiunea românească, în schimb, sugerează, inversînd prin contrasens raporturile de posesiune, că ingenium-ul ar aparține filozofiei („ingenium al filosofiei”): una este să spui că există un philosophisches Ingenium, că o parte a spiritului nostru este filozofică, alta să declari că filozofia posedă unul...

Să revenim la citatul din Mallarmé. În jurul acestui citat netradus de Benjamin se țes multe:

\section{Les langues imparfaites en cela que plusieurs, manque la suprême: penser étant écrire sans acces- soires, ni chuchotement mais tacite encore l'immortelle parole, la diversité, sur terre, des idiomes empêche personne de proférer les mots qui, sinon se trouveraient, par une frappe unique, elle-même matériellement la verité.}

Walter Benjamin nu indică sursa exactă a citării. Alexis Nouss o dă în notele ce însoțesc traducerea sa: citatul este extras din „Crise de vers”, care face parte din volumul Igitur. Divagations. Un coup de dés (Lamy \& Nouss, 1997, p. 23; citatul este extras din Mallarmé, 1976, p. 244). Antoine Berman, care o găsise înaintea lui Nouss, se mira, la seminarul său, că citarea fusese „denaturată, cenzurată!” (Berman, 2008, p. 157, și repetă, la pagina următoare, acuzația: „Benjamin l-a cenzurat”). Acuzația era fără îndoială excesivă, dar fapt este că Benjamin oprește citatul acolo unde Mallarmé, poetul, asocia, ceea ce nu are, desigur, a ne surprinde, „limba pură” cu limbajul poetic, $\mathrm{cu} \mathrm{versul}^{7}$, singurul înzestrat cu virtuți compensatoare, care să ne „despăgubească pentru imperfecțiunea limbilor” („rémunère le défaut des langues”, Berman, 2008, p. 158): or, limba pură a lui Benjamin nu era aceasta.

Decizia lui Benjamin de a nu traduce fraza nu a trecut neobservată: a provocat mirarea, curiozitatea, varii interpretări și o dorință înflăcărată de a înțelege din partea tuturor celor ce s-au aplecat asupra textului benjaminian: Jacques Derrida, Antoine Berman, Alexis Nouss, toți au descifrat în respectiva decizie, întrun fel sau altul, o ilustrare strălucită a intraductibilului, pe care au explicat-o ulterior, fiecare din propria-i perspectivă...

În principiu, decizia de a nu traduce citatul francez pierde întreaga sa valoare simbolică într-o singură limbă: franceza. Totuși, versiunea românească face și ea ca gestul lui Benjamin să devină caduc, traducînd citatul din Mallarmé în prima ediție, publicată în 2000. În cea de-a doua, apărută doi ani mai tîrziu, și care nu revizuiește practic nimic față de cea dintîi, citatul este dat totuşi în original, dar este tradus în limba română în singura notă de subsol (p. 45) a acestei versiuni. Mai mult, cum nu se precizează că nota îi aparține traducătorului (redactorului ?), se sugerează implicit că ea reflectă un gest similar al autorului textului original! Oricum ar sta lucrurile, prin această decizie, traducătoarea aduce atingere straturilor celor mai adînci de sens ale textului benjaminian și, în plus, mai face și ca toate paratextele care încearcă să-i descifreze simbolica, de la Jacques Derrida la Antoine Berman, trecînd prin Alexis Nouss și Laurent Lamy să devină incomprehensibile! Cu atît mai mult cu cît, cum se știe, textul lui Benjamin este o prefață, prefața la propria traducere a Tableaux parisiens de Baudelaire. Renunțind să traducă fraza lui Mallarmé, proclamîndu-i prin acest gest intraductibilitatea, lăsînd-o, cum spunea Derrida, „să strălucească precum medalia unui nume propriu" (numele propriu este intraductibil!), Benjamin declară implicit că sensul ei nu poate fi transpus într-o altă limbă fără „daune” (Derrida, 1998, p. 213), că restituirea sa este, prin consecință, imposibilă și, de asemenea, că „efectul de proprietate intraductibilă este legat mai puțin de un nume sau de adevărul de adecvare, cît de evenimentul unic al unei forțe performative" ${ }^{\prime}$. Prin acest

geniului limbii franceze s-a consolidat treptat, transformîndu-se într-un poncif persistent, susținut de două puncte de sprijin: claritatea și principiul ordinii „naturale”, care conduc la postulatul universalității acesteia. Cf. Meschonnic (1997, p. 227-240).

${ }^{7}$ Mallarmé spune, cîteva rînduri după fraza citată de Benjamin: „Seulement, sachons n'existerait pas le vers: lui, philosophiquement rémunère le défaut des langues, complément supérieur”, apud Berman (2008, p. 158), care dă citatul după Mallarmé (1965, p. 363-364).

${ }^{8}$ Traducerea ne aparține. Textul original spune: „briller comme la médaille d'un nom propre” (cf. Derrida, 1998, p. 213), iar versiunea engleză: „which he has left shining in his text like the medallion of a proper name” (Derrida, 2007, p. 202).

${ }^{9}$ Traducerea ne aparține. Textul original spune: „Et dans le texte de Mallarmé, l’effet de propriété intraduisible se lie moins 
gest, Benjamin destabilizează însuși conceptul de traducere și confirmă oarecum interpretarea dată de traducerea Nouss/Lamy, care decodau în Aufgabe mai degrabă un abandon decît o sarcină (sau poate chiar ambele).

Mai este însă ceva: Antoine Berman s-a întrebat și el de ce Benjamin nu a tradus fraza lui Mallarmé, cu atît mai mult cu cît, spunea el, aceasta nu este intraductibilă, nici din punct de vedere lingvistic, nici stilistic, chiar dacă dezvoltă o structură sintactică „dacă nu chiar absentă, în orice caz ciudat de rarefiată” 10 . După el, adevăratul motiv al refuzului de a traduce trebuie căutat în altă parte, în chiar sensul ei, pe care orice traducere, orice decizie ducînd spre traducere, l-ar fi contrazis „în registru ironic”, pentru că fraza „are de-a face cu imperfecțiunea limbilor, adică cu multitudinea lor și, prin urmare, cu ceea ce justifică în acelaşi timp necesitatea și imposibilitatea traducerii” ${ }^{11}$. Decizia traducătoarei distruge însăși coerența eseului benjaminian, întrucît a traduce această frază, care se construiește ca o abatere de la normă, ar fi totuna cu a traduce ceva ce a fost oarecum deja tradus, iar Derrida, între alții, a înțeles foarte bine acest lucru: nu traduci o traducere și, în orice caz, nu traduci un text care afirmă că nu este posibil să traduci. Poate că Benjamin nu a tradus citatul și pentru că l-a perceput ca fiind deja o traducere (Derrida, 1998, p. 218)...

Ca și ceilalți traducători, și Steven Rendall se întreabă de ce Benjamin a dat citatul dintr-un mare poet francez fără a-l traduce, inserîndu-l într-o prefață ce precede propria-i traducere dintr-un alt mare poet francez: el sugerează, între alte explicații posibile, că nu exista nici un motiv să-l traducă, pentru că acesta implica deja o decontextualizare similară procesului traducerii (Rendall, 1997, p. 179). A traduce citatul venea astfel în contradicție cu intenția, cu proiectul lui Benjamin și nici unul dintre traducătorii versiunilor englezești pe care le-am consultat nu a cedat în fața acestei „pulsiuni”. Mi s-a întîmplat totuși să dau peste o traducere engleză literală a frazei cu pricina, care îi transpune perfect sintaxa alterată, însă într-o lucrare a filozofului american Samuel Weber ${ }^{12}$ intitulată Benjamin's - abilities:

Languages, imperfect insofar as many, lacking the highest: thinking being writing without accessories, neither whispering but silent still the immortal word, the diversity, on earth, of idioms prevents no one from offering the words which, if not, would find themselves, in a single stroke, itself materially the truth (Weber, 2008, p. 75-76).

Am fi putut eventual acorda versiunii românești o intenție bună, „pedagogică”, de a veni în întîmpinarea receptorului român dacă ar fi optat pentru o transpunere literală a frazei mallarmeene ${ }^{13}$ : or, foarte departe de a fi literală, ea este traversată de la un capăt la altul de o intenționalitate în deplin dezacord nu doar cu ceea ce vrea să spună citatul, ci și cu intenția textului care-l găzduiește și care vorbește despre sarcina traducătorului. Acolo unde nu cade în contrasens, ea banalizează, anulează laconismul textului original, raționalizează sintaxa, introducînd verbe acolo unde nu există în textul sursă, și practică coordonarea: imperfecțiunea limbilor constă în pluralitatea lor și în lipsa celei supreme, ceea ce este redundant. În fine, atenuează considerabil registrul negativ în care se desfășoară acesta: manque (este substantivat în lipsa); sans accessoires, ni chuchotement (fără accesorii și fäă șoapte, coordonare ce uniformizează ritmul, dedramatizîndu-l); empêche personne (împiedicăpe toți); sinon (altfel). Textul este astfel total reorganizat după o concepție lineară, clasică, a sintaxei și ordinii cuvintelor. În plus, secvența tacite encore l’immortelle parole este tradusă prin contrasens prin cuvîntul nemuritor rămîne încă subînțeles, intercalîndu-se din nou

à du nom ou à la vérité d'adéquation qu’à l'unique événement d'une force performative” (Derrida, 1998). A fost transpus astfel în engleză: „And in Mallarmés text, the effect of being proper and thus untranslatable is tied less to any name or to any truth of adequation than to the unique occurrence of a performative force" (Derrida, 2007, p. 202).

${ }^{10},[\ldots]$ sinon absente, du moins étrangement raréfiée”, apud Berman (2008, p. 158).

${ }^{11}$, , [...] a trait à l'imperfection des langues, c'est-à-dire à leur multiplicité, et donc à ce qui fonde à la fois la nécessité et l'impossibilité de la traduction" (Berman, 2008, p. 158).

${ }^{12}$ Autorul a contribuit decisiv la receptarea lui Theodor W. Adorno și a Școlii de la Frankfurt, ca și a lui Jacques Derrida și Jacques Lacan în lumea anglo-saxonă.

${ }^{13} \mathrm{Nu}$ se specifică dacă a fost făcută de aceeași traducătoare sau extrasă dintr-o traducere anterioară a textului mallarmean. 
un verb. Cît despre fragmentul diversité, sur terre, des idiomes qui empêche personne de proférer les mots qui, sinon se trouveraient, par une frappe unique, elle-même matériellement la vérité, acesta este transpus în limba română prin diversitatea idiomurilor pe pamînt împiedică pe toți să profereze cuvinte care, altfel, la o atingere unică, s-ar materializa ca adevăr, ceea ce este un nonsens: textul francez spune că diversitatea idiomurilor nu împiedică pe nimeni să rostească cuvinte care, dacă acea diversitate nu ar exista, dacă nu ar exista decît limba supremă, s-ar materializa în Adevăr. Dacă textul lui Mallarmé este intraductibil, mai spunea Samuel Weber, nu înseamnă că el nu poate fi transcodat, doar că, traducîndu-l, căutînd să i se redea cu fidelitate sensul, se ratează esențialul, adică modul în care textul alege să spună ce are de spus: el este construit în jurul a trei fracturi ale normei gramaticale uzuale, ordinea cuvintelor este dezechilibrată, la fel și sintaxa, în aparență se produce un dezacord între subiect și verb, la suprême este subiectul real, les langues imparfaites, obiectul...

Nimic din toate acestea nu va putea vreodată să răzbată din versiunea românească, care decurge astfel dintr-un fel de „necugetare”, și al cărei unic merit este că solicită o nouă versiune, în stare să recunoască intraductibilul acolo unde el este, ca să spunem așa, „premeditat”, înscris în proiect și nu în obiect...

\section{Re-cunoașterea poeticii textului de tradus}

În aşa-numitele teorii funcționaliste ale traducerii, ca și în dezbaterea privind critica și evaluarea traducerilor, se insistă de la o vreme din ce în ce mai mult pe tipul de text de tradus, pe intenționalitatea pe care o exprimă el, văzîndu-se în aceasta însăși premisa adecvării tehnicilor de traducere, într-o ecuație de unde lipsește cu desăvîrșire amenințarea intraductibilului, gestionat ca o variabilă posibil de izolat și de evacuat în procesul traducerii. În aceste tipologii centrate pe criteriul funcției textului precumpănește implicit convingerea că orice proces traductiv comportă pierderi imposibil de ocolit: ideologia pe care se sprijină tehnicile de traducere pare obsedată de „gestionarea” imposibilității (teoretice) a traducerii și ea determină astfel elaborarea unor strategii ce urmăresc limitarea pierderilor, considerate ca fiind secundare și, ca atare, acceptabile, cu condiția ca actul traducerii să fie centrat pe producerea unui text țintă echivalent, în măsură să recompună funcția predominantă a textului sursă. Orientarea traducerii spre funcția dominantă a textului de tradus este astfel înălțată la rangul de principiu traductiv de bază: adecvarea traducerii nu se mai justifică în raport cu textul original, ci cu skopos-ul său, care îi dictează traducătorului strategiile de urmat ${ }^{14}$. Binomul fidelitate-traducere, ca și chestiunea intraductibilului sînt astfel dedramatizate printr-o operație de deplasare: fidelitatea nu mai asociază nemijlocit, printr-o legătură inevitabilă de filiație, textul țintă cu textul original, iar „trădarea” este justificată prin tehnici de traducere ce nu mai impun conformitatea directă vizavi de acesta. În schimb, poziția receptorului se consolidează în măsura în care funcția unui text este stabilită şi ținînd cont de efectul produs asupra acestuia ${ }^{15}$.

Actul traducerii textului filozofic pare a voi să mascheze o contradicție ce camuflează un fel de „profanare" a înseși intenționalității filozofice a textului, și anume transmiterea unor conținuturi universale. El însuşi traducător al lui Jürgen Habermas și Theodor W. Adorno, Jean-René Ladmiral vede în traducerea filozofiei un „scandal”, un gest aproape indecent, care aduce atingere Raţiunii, de vreme ce însăşi posibilitatea traducerii implică operațiuni ce disociază „semnificatele conceptuale ale filozofiei (ale unei filozofii?) de semnificanții limbii de plecare sau limbii originale [...] pentru a le înlesni apoi «reîncarnarea» în alte semnificate, străine, ale limbii de sosire sau limbii țintă în care este tradus textul" (Ladmiral, 1998, p. 990; cf. și Ladmiral, 1989, p. 6). Scandalul ar fi chiar dublu: pe de o parte, acest discurs, care vrea să exprime o Rațiune universală, nu poate evita „particularismul istoric și cultural al tradițiilor naționale” și, pe de altă parte, se vede obligat să se încarneze în „accidentele lingvistice, pe drept cuvînt numite idiomatice, ale limbilor naturale" (Ladmiral, 1998, p. 990). Traducerea acestui tip de text scoate astfel în evidență, în registrul scandalosului și al deriziunii, tensiunea internă a proiectului universalizant al raționalității filozofice, constrîns să accepte a fi transpus în semnificanţii unei limbi particulare. Profilul special al acestui

\footnotetext{
${ }^{14}$ Cf. Skopostheorie elaborată de Reiss \& Vermeer (1984).

${ }^{15}$ Am dezvoltat tema traducerii textului filozofic și în Jeanrenaud (2006, p. 251-285).
} 
„scandal” delimitează specificitatea textului filozofic și confirmă tensiunea provocată de incertitudinile ce planează asupra înseși posibilității traducerii sale, tensiune cu atît mai mare cu cît, în acest tip de text, „transparența rațională a semnificatelor conceptuale spre care tinde discursul filozofic [...] va fi întunecată de «impuritățile» contingente ale semnificantului lingvistic" (Ladmiral, 1998, p. 983). Textul filozofic este astfel definit ca un text centrat pe semnificat și care se remarcă prin punerea în valoare a capacităţii limbajului de a dobîndi statutul de metalimbaj; altfel spus, referentul discursului filozofic este propriul său semnificat - de aici și „scandalul” traducerii acestei categorii de texte (Ladmiral, 1998, p. 988). Textul filozofic poate fi inclus în categoria textelor literare în sens larg, dar, prin „tehnicitatea «jargonului» filozofic" (Ladmiral, 1998, p. 988) pe care-l utilizează, el face parte în egală măsură din categoria textelor tehnice, de care se desprinde însă deîndată dat fiind că subiectul care vorbește este omniprezent în text.

Propunîndu-și să scurtcircuiteze intraductibilul, mulți văd în textul filozofic o structură stratificată, care ar implica tehnici de traducere diferite: discursul acestui tip de text apare, pe de o parte, ca o arhitectonică alcătuită dintr-un palier constituit de un limbaj specializat și, pe de alta, ca o structură narativă, ca o povestire ce se înrudește cu textul de tip literar. Traducerea textului filozofic ar reprezenta astfel un caz foarte special de combinare a tehnicilor de traducere literale-pentru transpunerea terminologiilor-cu procedeele de traducere așa-zis „libere”, ,idiomatice”, pentru traducerea dispozitivului textual. Traducătorul ar avea astfel sarcina de a despărți limba utilizată în text, adică ceea ce ține de lexicul uzual al limbii sursă, de cuvîntul autorului, acel sistem de indicii ce pun amprenta unei subiectivități particulare (Ladmiral, 1994, p. 223). O asemenea viziune privind traducerea textului filozofic comportă totuși o sumă de riscuri, și nu dintre cele mai neînsemnate: ideologia din care decurge ea privilegiază sensul în detrimentul poeticii textului, a modalităţilor construcției sale, și generează o sumă de distorsiuni ale textului țintă, deformări explicative, adăugiri, peri- și parafraze ce pot distruge configurația originară.

De aici imperativul de a traduce nu doar retorica textului, ci și, mai ales, cu terminologia lui Henri Meschonnic, poetica lui (traducătorul este înclinat să le confunde, spune el): „Sarcina traducătorului lui Humboldt este să recunoască această poetică. Să o recunoască ca pe o poetică. Nu ca pe o retorică. Travaliul gîndirii dă naștere unei poetici dacă transformă valorile limbii în valori ale discursului, proprii doar discursului său. Iar dacă categoriile limbii rămîn categorii ale limbii, avem de-a face cu jocurile retoricii. Această banalitate, că nu putem separa o gîndire de scrierea ei. Traducătorului îi revine sarcina de a nu confunda poetica cu o retorică, la toate nivelele pe care le deosebește lingvistica tradițională” (traducerea îmi aparține, cf. Meschonnic, 1999, p. 350). Examinînd traducerile franceze ale textelor lui Wilhelm von Humboldt, Meschonnic constată că traducerea diferențiată a textului filozofic văzut ca suprapunerea etanșă a două straturi, pe de o parte terminologia, pe de alta textualizarea ei formală, comportă pericole serioase: dacă traducerea terminologiei s-a făcut respectînd corespondențele, „în schimb, operatorii, ritmul logic, [...] sînt tratați ca un element unde variația este lipsită de importanță. Textul este respectat în rigoarea lui, dar această rigoare este doar de natură substanțială, conceptuală. Își face astfel loc o anumită idee despre textul filozofic: în afara tehnicității-care presupune confuzia dintre concept și cuvînt—tot restul este literatură. Adică retorică. O asemenea concepție despre limbaj ține cont doar de semn. De primatul semnificatului identificat cu semnul” (Meschonnic, 1999, p. 382).

Această metodă camuflează o ideologie dublă (duplicitară?) privind actul traducerii; Henri Meschonnic pare a sugera acest lucru atunci cînd afirmă că traducerea lexicului specializat prin corespondențe exprimă la urma urmelor confuzia dintre concept și cuvînt, în măsura în care garanția reușitei traducerii este ancorată în convingerea că redarea sensului depinde de posibilitatea menținerii lor în toate ocurențele textului sursă. Jean-René Ladmiral, ale cărui foarte cunoscute „teoreme” (Ladmiral, 1994) traductologice militează pentru dreptul de a practica ,anexionismul” în traducere, vede în acest procedeu prelungirea unei „metafizici substanțialiste” ${ }^{16}$ asupra limbajului, care tinde să sacralizeze limba sursă, să supraevalueze valențele ei expresive, cu consecința supradilatării pericolului de a cădea în capcana aporiei traductibilintraductibil. Dramatizarea fracturii dintre ce este și ce nu este traductibil va submina astfel într-o măsură

\footnotetext{
${ }^{16}$ Jean-René Ladmiral, Traduire: théorèmes pour la traduction, Éditions Payot, Paris, 1979, apud Brownlie (2002, p. 306).
} 
şi mai mare întreprinderea traducerii textului filozofic care, prin chiar natura sa, exprimă, într-un registru tensionat, „coincidența între singularitatea individuală și universalitate” ${ }^{17}$.

\section{Cum se traduce o ,traducere”?}

Al doilea citat dat de Walter Benjamin este extras din Die Krisis der europäischen Kultur de Rudolf Pannwitz (Pannwitz, 1917): din nou, avem de-a face cu un text cu o sintaxă alterată, la care se mai adaugă și eliminarea oricărei punctuații și a majusculelor pentru substantivele comune și pentru începuturile de frază, așa cum obișnuiau să scrie Jakob Grimm sau Stefan George (Berman, 2008, p. 159). Citatul este alcătuit din două fraze care se încheie cu un punct, dar nici una nu începe cu majusculă. Între cele două citate, care au același tip de structură formală, se țes destule legături: ignorînd sintaxa, ambele mizează pe cuvînt, care este smuls, eliberat din potențialele sale rețele sintactice. Ridicat la rangul de substantiv propriu, rațiunea de a fi a cuvîntului devine astfel relația directă cu referentul ${ }^{18}$ : or, și pentru Benjamin traducerea este o operațiune ce are de-a face cu cuvîntul. Aici trebuie căutată rațiunea alegerii celor două citate: „[...] germana lui Pannwitz, ca și franceza lui Mallarmé subminează structura lingvistică a limbajului şi mai ales sintaxa sa—şi se poate considera că rolul lor constă în a fi îndeplinit acea eliberare a cuvintului pe care se consideră că are a o înfăptui traducerea” (Rendall, 1997, p. 180; traducerea îmi aparține).

Restabilirea, prin traducerea celor două citate (din care unul nu are a fi tradus), a ordinii sintactice distruge nu doar obiectivul lor, ci și rațiunea lor de a $f i$ în textul lui Benjamin. Am mai spus-o: întrun anume fel, cele două citate sînt deja niște traduceri (intralingvistice), pentru că violentează sintaxa și eliberează cuvîntul după principii traductive similare celor preconizate de Benjamin. De aceea sînt ele intraductibile, iar Benjamin o spune limpede: „Übersetzungen dagegen erweisen sich unübersetzbar nicht wegen der Schwere, sondern wegen der allzu großen Flüchtigkeit, mit welcher der Sinn an ihnen haftet" 19 sau: „Übersetzung ist eine Form. Sie als solche zu erfassen, gilt es zurückzugehen auf das Original. Denn in ihm liegt deren Gesetz als in dessen Übersetzbarkeit beschlossen"20.

Dintre cele șase traduceri pe care le-am consultat, una singură îndrăznește să redea forma textului lui Pannwitz (a se vedea Anexa B). Celelalte încearcă doar să sugereze particularitățile sale formale în diverse grade, dar sfirșesc totuși prin a introduce, ici și colo, virgule și puncte finale. Antoine Berman reface frazele, care încep acum cu majuscule, dar nu introduce nici un semn de punctuație în interiorul lor; în schimb, traduce, conformîndu-se uzului, seria wort bild ton prin mot, image et son (un et precede ultimul termen

${ }^{17}$ Ibid. Cf. Jean-René Ladmiral, La traduction philosophique, in „Revue de Phonétique Appliquée”, apud Brownlie (2002).

${ }^{18}$ Cf. Rendall (1997, p. 179). Rendall se întreabă și de ce a ales Benjamin tocmai acest citat din Pannwitz, deși mai logic ar fi fost să-i invoce pe Schleiermacher sau Humboldt.

${ }^{19}$ Benjamin (1972, p. 20). Cf. versiunea Lamy \& Nouss (1997, p. 27): „Les traductions, par contre, se révèlent intraduisibles, non pas à cause du poids que le sens fait peser sur elles, mais parce qu'il s'attache à elles de façon beaucoup trop fugitive”; versiunea Catrinel Pleșu: „Traducerile, pe de altă parte, se dovedesc a fi intraductibile nu din cauză că sensul le împovărează prea mult, ci din cauză că le afectează mult prea în treacăt” (Benjamin, 2002, p. 47). Faţă de caracterul „fugitiv” al modului în care sensul se asociază traducerii din versiunea Nouss/Lamy, formularea prin care sensul „afectează” traducerile „mult prea în treacăt" pare improprie și, în plus, bagatelizează complexitatea ideii exprimate de textul sursă.

Versiunea Zohn: „Translations, in contrast, prove to be untranslatable not because of any inherent difficulty but because of the looseness with which meaning attaches to them” (Benjamin, 1968, p. 80). Versiunea Rendall: „Translations, on the contrary, prove to be untranslatable not because meaning weighs on them heavily, but rather because it attaches to them all too fleetingly" (Benjamin, 1997, p. 164).

${ }^{20}$ Benjamin (1972, p. 9). Versiunea Nouss/Lamy: „La traduction est une forme. Pour la saisir comme telle il faut revenir à l'original. En effet, c'est en lui que repose sa loi, telle qu'elle est contenue dans sa traductibilité" (Lamy \& Nouss, 1997, p. 14). Versiunea Catrinel Pleșu: „Traducerea este o formă. Pentru a o înțelege ca formă, trebuie să ne întoarcem la original, căci în el este cuprinsă legea care guvernează traducerea, și anume traductibilitatea sa” (Benjamin, 2002, p. 39). Spre deosebire de Nouss/Lamy, care mențin cu strictețe structura sacadată a acestei concatenări de trei propoziții cu un crescendo argumentativ, versiunea românească leagă ultimele două propoziții din textul original, atenuîndu-le astfel impactul într-o explicitare excesivă, ratînd însuși ritmul, poetica lor. Versiunea Rendall: „Translation is a mode. In order to grasp it as such, we have to go back to the original. For in it lies translation's law, decreed as the original's translatability" (Benjamin, 1997, p. 152). Versiunea Zohn: „Translation is a mode. To comprehend it as mode one must go back to the original, for that contains the law governing the translation: its translatability" (Benjamin, 1968, p. 69). 
al enumerării); Nouss și Lamy refac masiv structura frastică, multiplicînd punctele finale ale frazelor și introducînd în două rînduri punct-virgulă; în schimb, suprimă punctele de suspensie din textul original. În fine, traducerea lui Gandillac reconstituie atît întreaga punctuație, cît și structura frastică. Versiunile Zohn și Catrinel Pleșu se supun în totalitate uzului și restaurează absolut toate abaterile textului original, ortografice, sintactice, structura frazei, majusculele de la începutul propozițiilor. Doar versiunea Rendall îndrăznește să transpună integral textul lui Pannwitz, adică și forma lui, dar ea recurge la o omisiune cu totul surprinzătoare, suprimînd primul termen din seria wort bild ton. Însă nici Rendall nu găsește o soluție pentru „transpunerea” minusculelor substantivelor comune din textul sursă. Nimeni nu pare a se fi gîndit la posibilitatea, totuși plauzibilă, de a reda bizareria substantivelor germane scrise cu minuscule procedînd invers, adică transcriind, în engleză, franceză, română, substantivele cu majuscule. Desigur, s-ar putea obiecta că luarea unei astfel de decizii, în limbi în care substantivul comun începe minusculă, ar asocia, personificîndu-le, o valoare simbolică, alegorică: dar dacă respectiva tehnică s-ar aplica la toate substantivele și la începuturile de frază, cititorul și-ar da, poate, seama că nu este vorba de o deplasare a substantivelor în registru simbolic, ci de altceva. Rămîne însă, desigur, faptul că a scrie, în germană, substantivele comune fără majuscule este o decizie imediat percepută ca o violare a unei constrîngeri ortografice, în timp ce a le scrie cu majuscule în franceză, engleză sau română nu va putea fi niciodată perceput ca o abatere de la normă.

Unii traducători simt nevoia de a se justifica, ceea ce înseamnă că decizia de a normaliza traducerea le provoacă o stare de disconfort: Berman (2008, p. 179) retraduce parțial versiunea lui Gandillac, încercînd să păstreze caracterul oral al textului sursă și afirmă, cu timiditate, că acesta nu ar trebui să fie „pieptănat”, ci „,ă i se lase aspectul oarecum despieptănat” (p. 178); Nouss și Lamy, care îndrăzniseră totuși să traducă titlul prin „L'abandon du traducteur”, par dintr-o dată timorați, şi recunosc într-o notă, fără însă a-și justifica suficient decizia, că nu au fost „destul” de fideli textului sursă, „de vreme ce restabilim o punctuație a cărei omisiune ni se pare că ar duce la confuzie” (...).

Or, forma - care reproduce registrul oral—pentru care a optat Pannwitz are o legătură cu ce vrea el să spună, iar acest raport nu l-au sesizat și prin urmare nu l-au tradus nici Zohn și nici Catrinel Pleșu: atît prin formă, cît și prin conținut, textul lui Pannwitz trimite la esența orală a limbii, acolo unde „cuvîntul, imaginea și sunetul se întîlnesc” (Berman, 2008, p. 179), iar menționarea „dialectului” ar fi trebuit fără îndoială să le atragă atenția. După Antoine Berman, citatul constituie o autentică „spunere istorică” (p. 178) despre traducere, care ne privește din două puncte de vedere: pe de o parte, prin „coliziunea”, comoția limbilor pentru care depune mărturie—fără a încerca să o instituie—și, pe de alta, prin „deplasarea pînă la «elementele ultime » ale limbii înseși, acolo unde cuvîntul, imaginea și sunetul se întîlnesc—ca de la dialect la dialect” (Berman, 2008, p. 179) 21. Textul lui Pannwitz trimite la însăși esența „orală” a limbii, iar dialectul nu este invocat întîmplător: „Căci toate limbile sînt Limba în măsura în care sînt dialecte. Nu există: limbajul - limbile (de la gen la specie), ci limba - dialectele. Spațiul în care se desfăşoară traducerea ca intenție de a fi literă a limbii este dialectul. Franceza și chineza sînt dialecte ale aceleiași limbi” (Berman, 2008, p. 179).

\footnotetext{
${ }^{21}$ Berman nu ratează ocazia de a-l ironiza pe Meschonnic, mirîndu-se că acesta a citat textul „atribuindu-l lui Benjamin”, și continuă, pe un ton foarte apăsat, „desigur, cine l-a citit pe Pannwitz?", iar pentru a răsuci și mai tare cuțitul în rană, adaugă: „Dar și aici, avem de-a face cu declarații istorice despre traducere”. Berman nu spune însă unde a făcut Meschonnic o asemenea confuzie. Citind răutăcioasa observație, mi-am spus mai întîi că aveam de-a face cu un „lapsus revelator” și că, poate, eroarea lui Meschonnic demonstra, pe de altă parte, în ce grad citatul și textul lui Benjamin se contopeau, în ce grad unul îl susținea pe celălalt și că toți traducătorii aveau datoria să redea această fuziune... Am avut totuși o îndoială și am căutat îndelung în lucrările lui Meschonnic pînă cînd, în cele din urmă, am găsit ce căutam. În Pour la poétique, Meschonnic spune (traducerea îmi aparține): „Parafrazînd un pasaj citat de Benjamin, aș spune că, în loc să francizeze sanscrita, greaca, engleza, trebuie să sanscritizăm, să elenizăm, să anglicizăm franceza”; apoi, șapte rînduri mai jos, vorbind despre „dialectica contradicțiilor procesului traducerii”, el afirmă că ea „duce la această formulare a lui Benjamin” și citează a doua parte din citatul din Pannwitz: ca și în cazul citatului din Mallarmé, Berman avea dreptate doar pe jumătate și poate că mai important ar fi fost să observe nu că Meschonnic îi atribuia lui Benjamin un segment din textul lui Pannwitz, ci că omitea să specifice că cita ceea ce Gandillac, traducătorul, spunea că spune Benjamin... Cf. Meschonnic (1973, p. 143).
} 
În această lectură, opera - care înlocuiește cuvîntul în versiunea engleză și în versiunea româneascăface să apară un teribil contrasens: să asimilezi cuvîntul la cuvîntul scris acolo unde se vorbește de dialecte, să-l transpui, prin metonimie, în operă, abolește, anulează cu desăvîrșire valoarea și sensul triadei cuvîntimagine-sunet. Versiunea românească, ca şi în cea engleză de altminteri (ca să nu mai vorbim de cea care suprimă total wort), nu doar fac să devină ininteligibile citatul și textul lui Benjamin, dar îi și deturnează cu desăvîrșire sensul; seria work, image and tone // opera, imaginea și tonul ${ }^{22}$ deviază lectura spre scriptural, spre scriitură, îndepărtîndu-se de la însăși esența dialectalului, în cazul de față, oralitatea despre care vorbește Pannwitz.

În fine, cuvîntul, imaginea, tonul nu sînt convergente, ca în versiunile Pleșu și Zohn: ipoteza lor de sens deviază masiv din cauza asimilării metonimice și inevitabil retorizante a cuvîntului cu opera și instaurează o altă coerență $\breve{2}^{23}$, care face ca oralitatea dialectală să devină caducă; traducătorul ar trebui să dorească să ajungă acolo unde are loc confluența lor, acolo unde cuvîntul, imaginea, tonalitatea se întîlnesc, nu acolo unde converg ele (converge) și cu atît mai puțin acolo unde sînt convergente. Doar așa ar putea el să pătrundă în adîncurile propriei limbi, să o despăturească, nu prin intermediul (by means of // prin intermediul), ci datorită limbii străine.

Raporturile care se țes între citatul din Pannwitz și eseul lui Benjamin sînt astfel menite să rămînă pentru totdeauna invizibile pentru cititorii versiunilor Zohn, Rendall și Pleșu. Punînd în valoare dialectalul, citatul deschide calea către oralitatea acelei Reine Sprache, limba pură, care ar fi astfel dialectul sau, mai exact, „esența dialectală a limbii” (Berman, 2008, p. 181): „Fie că este vorba de poezie, de teatru, de cărți pentru copii, de roman, de psihanaliză, de texte religioase, juridice... traducerea operelor are de-a face cu oralitatea”, avertizează Berman (p. 180). Iar scriitura, insistă el, include oralitatea: „Scrierea nu este nicicînd atît de ascultată ca atunci cînd oralitatea este înscrisă în ea. Limba însăși este limba orală” (p. 180). Traducerea este acel act în măsură, singurul în măsură, să „elibereze în originalul scris încărcătura sa de oralitate" (p. 180).

La capătul acestui parcurs rămîne o întrebare, la care nu știu ce răspuns să dau: de ce traducătorii, cei care au înțeles miza citatului lui Pannwitz, care l-au interpretat și comentat cu atîta strălucire-Berman, Nouss, Lamy și Rendall—, nu au îndrăznit să-l traducă în litera şi în spiritul său? Prin tratamentul aplicat citatului, ei au atins punctul culminant al trădării, deoarece au trădat și litera și sensul și, prin acest gest, au trădat însăși coerența textului unde este inserat acesta și care este un text ce vorbește despre sarcina traducătorului ${ }^{24}$.

\section{Bibliografie}

Benjamin, W. (1968). The Task of the Translator, în Illuminations, Essays and Reflections, ed. Hannah Arendt, new preface by Leon Wieseltier, traducere din limba germană de Harry Zohn, Random House, New York.

Benjamin, W. (1971). La Tâche du traducteur, în Mythe et violence, traducere din limba germană de Maurice de Gandillac, Denoël, Paris.

Benjamin, W. (1972). Die Aufgabe des Übersetzers, în Gesammelte Schriften, Bd. IV/1, Suhrkamp Verlag, Frankfurt/Main, p. 921.

Benjamin, W. (1991). La Tâche du traducteur, traducere din limba germană de Broda, Martine, în „Po\&sie”, nr. 55, martie, număr intitulat „Poésie à Berlin”.

Benjamin, W. (1997). The Translator's Task, traducere din limba germană de Steven Rendall, în „TTR : traduction, terminologie, rédaction", vol. 10, nr. 2, p. 151-165, CrossRef.

Benjamin, W. (2000a). La Tâche du traducteur, în OEuvres I, traducere din limba germană de M. De Gandillac, P. Rusch și R. Rochlitz, Éditions Gallimard, Paris.

Benjamin, W. (2000b). Sarcina traducătorului, în Benjamin, W., Iluminări, traducere din limba germană de Catrinel Pleșu, Editura Univers, București.

\footnotetext{
${ }^{22}$ Poate tonalitate? De remarcat ezitarea traducătorilor între ton și son.

${ }^{23}$ Care întreține un raport cu raționalizarea discursului, cu nivelarea sa și cu tendințele deformante teoretizate de același Berman (1999, p. 49-68).

${ }^{24}$ Confirmînd în registru ironic dificultatea tentativei de delimitare a fidelității de infidelitate, limba română, şi datorită lui Ion Luca Caragiale, a găsit modul de a găzdui în sfera semantică a aceluiași cuvînt trădarea și traducerea...
} 
Benjamin, W. (2002). Sarcina traducătorului, în Benjamin, W., Iluminări, traducere din limba germană de Catrinel Pleșu, Editura Idea Design\&Print, Cluj-Napoca.

Berman, A. (1999). La traduction et la lettre ou l'Auberge du lointain, Éditions du Seuil, Paris, p. 49-68.

Berman, A. (2008). L'áge de la traduction. „La tâche du traducteur” de Walter Benjamin. Un commentaire, text reconstituit de Isabelle Berman în colaborare cu Valentina Sommella, Presses Universitaires de Vincennes, Paris.

Brownlie, S. (2002). La traduction de la terminologie philosophique, în „Meta: journal des traducteurs”, vol. 47, nr. 3, p. 296-310, CrossRef.

Cassin, B. (éd.) (2004). Vocabulaire européen des philosophies. Dictionnaire des intraduisibles, Éditions du Seuil/Le Robert, Paris. Compagnon, A. (1998). Le démon de la théorie, Éditions du Seuil, Paris.

Derrida, J. (1998). Des Tours de Babel, în Psyché. Inventions de l'autre, Éditions Galilée, Paris.

Derrida, J. (2007). Des Tours de Babel, în Kamuf, P. \& Rottenberg, E. (ed.), Psyche. Inventions of the Other, vol. I, traducere din limba franceză de Joseph F. Graham, Stanford University Press, Stanford, CA.

Jakobson, R. (1959). On linguistic aspects of translation, în Brower, R.A. (ed.), On Translation, Harvard University Press, Cambridge, MA, p. 232-239, CrossRef.

Jakobson, R. (1963). Essais de linguistique générale, traducere din limba engleză și prefaţă de Nicolas Ruwet, Éditions de Minuit, Paris.

Jakobson, R. (1971). Selected Writings, II. Word and Language, Mouton, The Hague, CrossRef.

Jeanrenaud, M. (2006). Universaliile traducerii. Studii de traductologie, cuvînt înainte de Gelu Ionescu, Polirom, Iași - București. Jeanrenaud, M. (2012). La traduction, là où tout est pareil et rien n’est semblable, prefață de Claude Hagège, EST, Paris.

Ladmiral, J.-R. (1989). Pour une philosophie de la traduction, în „Revue de métaphysique et de morale. La traduction philosophique", nr. 1, Éditions Armand Colin, Paris.

Ladmiral, J.-R. (1994). Traduire: théorèmes pour la traduction, Éditions Gallimard, Paris.

Ladmiral, J.-R. (1998). Principes philosophiques de la traduction, în Encyclopédie philosophique universelle, ediție coordonată de André Jacob, vol. IV, PUF, Paris.

Lamy, L. \& Nouss, A. (1997). Labandon du traducteur : Prolégomènes à la traduction des « Tableaux parisiens 》 de Charles Baudelaire, în „TTR : traduction, terminologie, rédaction”, vol. 10, nr. 2, p. 13-69, CrossRef.

Mallarmé, S. (1965). CEuvres complètes, „Bibliothèque de la Pléiade”, Éditions Gallimard, Paris.

Mallarmé, S. (1976). Igitur. Divagations. Un coup de dés, Éditions Gallimard, Paris.

Meschonnic, H. (1973). Pour la poétique, II. Épistémologie de l'écriture. Poétique de la traduction, Éditions Gallimard, Paris.

Meschonnic, H. (1997). De la langue française. Essai sur une clarté obscure, édition revue et augmentée, Éditions HachetteLittératures, Paris.

Meschonnic, H. (1999). Poétique du traduire, Éditions Verdier, Paris.

Mounin, G. (1994). Les Belles Infidèles, ediția a 2-a, Presses Universitaires de Lille, Lille (ed. I-a: 1955).

Pannwitz, R. (1917). Die Krisis der europäischen Kultur, Hans Carl Verlag, Nürnberg.

Pavel, Th. (1988). Le mirage linguistique. Essai sur la modernisation intellectuelle, Éditions de Minuit, Paris.

Reiss, K. \& Vermeer, H. (1984). Grundlegung einer allgemeinen Translationstheorie, Niemeyer, Tübingen.

Rendall, S. (1997). Translation, Quotation, Iterability, în „TTR: traduction, terminologie, rédaction”, vol. 10, nr. 2, p. 167-189, CrossRef.

Venuti, L. (ed.) (2000). The Translation Studies Reader, Routledge, London - New York.

Weber, S. (2008). Benjamin's - abilities, Harvard University Press, Cambridge MA / London.

\section{Anexa A.}

\section{Benjamin (1972)}

Denn es gibt ein philosophisches Ingenium, dessen eigenstes die Sehnsucht nach jener Sprache ist, welche in der Übersetzung sich bekundet „Les langues imparfaites en cela que plusieurs, manque la suprême: penser étant écrire sans accessoires, ni chuchotement mais tacite encore l'immortelle parole, la diversité, sur terre, des idiomes empêche personne de proférer les mots qui, sinon se trouveraient, par une frappe unique, elle-même matériellement la verité." Wenn, was in diesen Worten Mallarmé gedenkt, dem Philosophen streng ermeßbar ist, so steht mit ihren Keimen solcher Sprache die Übersetzung mitten zwischen Dichtung und der Lehre. Ihr Werk steht an Ausprägung diesen nach, doch es prägt sich nicht weniger tief ein in die Geschichte.

\section{Lamy \& Nouss (1997)}

Car il existe un ingenium philosophique dont le trait le plus spécifique est la nostalgie de cette langue qui s'annonce dans les traductions. „Les langues imparfaites en cela que plusieurs, manque la suprême: penser étant écrire sans accessoires, ni chuchotement mais tacite encore l'immortelle parole, la diversité, sur terre, des idiomes empêche personne de proférer les mots qui, sinon se trouveraient, par une frappe unique, elle-même matériellement la vérité." Si ce que pense Mallarmé en ces termes est applicable en toute rigueur au philosophe, alors la traduction, grosse 
des germes d'une telle langue, se tient au point médian entre l'œuvre poétique et la doctrine. Son action est moins marquée mais laisse une trace tout aussi profonde dans l'histoire.

\section{Benjamin (1968)}

For there is a philosophical genius that is characterized by a yearning for that language which manifests itself in translations. „Les langues imparfaites en cela que plusieurs, manque la suprême: penser étant écrire sans accessoires, ni chuchotement mais tacite encore l'immortelle parole, la diversité, la terre, des idiomes empêche personne de proférer les mots qui, sinon se trouveraient, par une frappe unique, elle-même matériellement la vérité". If what Mallarmé evokes here is fully fathomable to a philosopher, translation, with its rudiments of such a lunaguage, is midway between poetry and doctrine. Its products are less sharply defined, but it leaves no less of a mark on history.

\section{Benjamin (2000b)}

Căci exista un ingenium al filosofiei, care este caracterizat de nostalgia acestei limbi care se anunță în traduceri: „Imperfecțiunea limbilor constă în pluralitatea lor și in lipsa celei supreme: a gîndi înseamnă a scrie fără accesorii și fără șoapte, cuvintul nemuritor rămîne încă subînțeles, diversitatea idiomurilor de pe pămînt împiedică pe toți să profereze cuvinte care, altfel, la o atingere unică, s-ar materializa ca adevăr”. Dacă ceea ce spune Mallarmé aici se poate aplica, cu toată rigoarea, filosofului, atunci traducerea, cu germenii acestei limbi pe care îi poartă în ea, este la jumătatea distanței dintre creația literară și teorie. Cu toate că operele ei sînt mai puțin riguros reliefate, nu lasă urme mai puțin adînci în istorie.

\section{Benjamin (2002)}

Căci există un ingenium al filosofiei, care este caracterizat de nostalgia acestei limbi care se anunţă în traduceri: „Les langues imparfaites en cela que plusieurs, manque la suprême: penser étant écrire sans accessoires, ni chuchotement mais tacite encore l'immortelle parole, la diversité, sur terre, des idiomes empêche personne de proférer les mots qui, sinon se trouveraient, par une frappe unique, elle-même matériellement la verité.”* Dacă ceea ce spune Mallarmé aici se poate aplica, cu toată rigoarea, filosofului, atunci traducerea, cu germenii acestei limbi pe care îi poartă în ea, este la jumătatea distanței dintre creația literară și teorie. Cu toate că operele ei sînt mai puțin riguros reliefate, nu lasă urme mai puțin adînci în istorie. ( ${ }^{*}$ Nota de subsol: „Imperfecțiunea limbilor constă în pluralitatea lor și în lipsa celei supreme: a gîndi înseamnă a scrie fără accesorii și fără șoapte, cuvîntul nemuritor ramîne încă subînțeles, diversitatea idiomurilor pe pamînt împiedică pe toți să profereze cuvinte care, altfel, la o atingere unică, s-ar materializa ca adevăr")

\section{Anexa B.}

\section{Benjamin (1972)}

Dort heiß es: „unsre übertragungen auch die besten gehn von einem falschen grundsatz aus sie wollen das indische griechische englische verdeutschen anstatt das deutsche zu verindischen vergriechischen verenglischen. sie haben eine viel bedeutendere ehrfurcht vor den eigenen sprachgebräuchen als vor dem geiste des fremden werks ... der grundsätzliche irrtum des übertragenden ist dass er den zufalligen stand der eignen sprache festhält anstatt sie durch die fremde sprache gewaltig bewegen zu lassen. er muss zumal wenn er aus einer sehr fernen sprache überträgt auf die letzten elemente der sprache selbst wo wort bild ton in eins geht zurück dringen er muss seine sprache durch die fremde erweitern und vertiefen man hat keinen begriff in welchem masze das möglich ist bis zu welchem grade jede sprache sich verwandeln kann sprache von sprache fast nur wie mundart von mundart sich unterscheidet dieses aber nicht wenn man sie allzu leicht sondern gerade wenn man sie schwer genug nimmt”. (cf. Pannwitz, 1917, p. 240).

\section{Lamy \& Nouss (1997)}

On y lit: „nos traductions, et même les meilleures, partent d'un principe erroné si elles entendent germaniser l'indien, le grec, l'anglais, au lieu d'indianiser, gréciser, angliciser l'allemand. elles ont beaucoup plus de respect pour les usages de leur propre langue que pour l'esprit de l'œuvre étrangère. l'erreur fondamentale du traducteur est de s'en tenir à l'état aléatoire de sa propre langue, au lieu d'être animé par le mouvement puissant de la langue étrangère. surtout lorsqu'il traduit d'une langue très lointaine, il lui faut remonter aux éléments ultimes de la langue même, où mot, image et ton ne font qu'un; il doit élargir et approfondir sa langue grâce à la langue étrangère. on ne dispose d'aucun concept pour évaluer dans quelle mesure cela est possible, jusquà quel degré chaque langue peut se transformer; de langue à langue on observe pratiquement la même distance que de dialecte à dialecte, non quand on les prend trop légèrement, cependant, mais bien plutôt quand on les considère avec suffisamment de sérieux." 
Berman (2008)

„[...] nos traductions même les meilleures partent d'un faux principe elles veulent germaniser l'indien le grec l'anglais au lieu d'indianiser de gréciser d'angliciser l'allemand. Elles ont bien plus de respect face aux usages propres de la langue que devant l'esprit de l'œuvre étrangère. [...] L'erreur fondamentale du traduisant est qu'il maintient l'état fortuit de sa propre langue au lieu de se laisser puissamment mouvoir par la langue étrangère (trad. Berman). Surtout lorsqu'il traduit d'une langue très éloignée, il lui faut remonter aux éléments ultimes du langage même, là où se rejoignent mot, image, son; il lui faut élargir et approfondir sa propre langue grâce à la langue étrangère; on n'imagine pas à quel point la chose est possible; jusquà quel degré une langue peut se transformer; de langue à langue il n'y a guère plus de distance que de dialecte à dialecte, mais cela non point quand on le prend trop à la légère, bien plutôt quand on les prend assez au sérieux". (cf. traducerea lui Maurice de Gandillac)

\section{Benjamin (1968)}

Pannwitz writes: „Our translations, even the best ones, proceed from a wrong premise. They want to turn Hindi, Greek, English into German instead of turning German into Hindi, Greek, English. Our translaters have a far greater reverence for the usage of their own language than for the spirit of the foreign works... The basic error of the translator is that he preserves the state in which his own language happens to be instead of allowing his language to be powerfully affected by the foreign tongue. Particularly when translating from a language very remote from his own he must go back to the primal elements of language itself and penetrate to the point where work, image, and tone converge. He must expand and deepen his language by means of the foreign language. It is not generally realized to what extend this is possible to what extend any language can be transformed, how language differs from dialect; however, this last is true only if one takes language seriously enough, not if one takes it lightly".

\section{Rendall (1997)}

He writes: „our translations even the best start out from a false principle they want to germanize Indic Greek English instead of indicizing, graecizing, anglicizing German. they are far more awed by their own linguistic habits than by the spirit of the foreign work [...] the fundamental error of the translator is that he holds fast to the state in which his own language happens to be rather than allowing it to be put powerfully in movement by the foreign language. he must in particular when he is translating out of a language very distant from his own penetrate back to the ultimate elements of the language at that very point where image tone meld into one he must broaden and deepen his own language through the foreign one we have no notion how far this is possible to what degree each language can transform itself one language differentiates itself from another almost as one dialect from another but this happens not when they are considered all too lightly but only when they are considered with sufficient gravity".

\section{Benjamin (2000b, 2002)}

Pannwitz spune: „Chiar și cele mai bune traduceri ale noastre pornesc de la o premisă greșită. Ele vor să germanizeze hindi, greaca, engleza, în loc să hindizeze, grecizeze și anglicizeze germana. Au un respect mult mai mare faţă de obiceiurile limbii lor decît față de spiritul operelor străine... Eroarea fundamentală a traducătorului constă în faptul că-și menține propria limba în starea în care se află întîmplător, în loc să-i permită să fie puternic afectată limba străină. Mai ales atunci cînd traduce dintr-o limbă care este foarte îndepărtată de a sa, trebuie să se întoarcă la elementele ultime ale limbii înseși, acolo unde opera, imaginea și tonul sînt convergente. Trebuie să extindă şi să aprofundeze propria limba prin intermediul limbii străine. În general, nu se știe în ce măsură este posibil acest lucru, în ce măsură se poate transforma o limbă; distanța de la o limbă la alta nu este mai mare decît de la un dialect la altul, de aceea, limba nu trebuie tratată cu ușurință, ci luată în serios." 